\title{
Sanatın Yaratılma Sürecinde Kadının İşlevi
}

\author{
Özlem Nemutlua
}

Özet

Baş kişisi yazar/şair erkek olan bazı roman ve hikâyelerde, sanat eserinin verilme süresinde kadın karakterlerin oldukça işlevsel bir şekilde kurgulandıklarını görürüz. Türk romanının en yetkin ilk örneklerinden Mai ve Siyah'ta (Halit Ziya Uşaklıgil) Lamia'ya kavuşmak, meşhur bir şair ve matbaa sahibi olmakla birlikte, Ahmet Cemil'in üç büyük hayalinden biridir. Tanpınar'ın da bahsettiği gibi Lamia, sade bir sevgili değil Ahmet Cemil'in ulaşmak istediği hayat tarzı ve refah seviyesinin (Bunların hepsi iyi bir şair olmaya bağlıdır) bir sembolüdür. Tanpınar bir bakıma Huzur'unda şair ruhlu akademisyen Mümtaz'ın hayatında Nuran'ın oynadığı rolü tasvir ederken Ahmet Cemil'i bir nebze de olsa hayallerine kavuşturmak ister gibidir. Yakup Kadri'nin sanatında bir dönüm noktası teşkil eden "Rahmet" hikâyesinde baş kişisi yazar olan erkek karakterin toplumun ve milletin acılarını terennüm eden bir edebiyat anlayışını benimsemesinde, sevdiği kadının dünyasını reddetmesi ve ondan uzaklaşması çok önemlidir. Sabahattin Ali'nin “Kurtarılamayan Şaheser" hikâyesinde de ideal ve özgün bir eserin yaratılma sürecini adım adım bir kadın karakterin yönlendirdiğini ve hatta neticelendirdiğini görürüz. Aynı yazarın "Viyolensel" hikâyesinde bir şair ve yazar olmamakla birlikte bir müzisyenin sevdiği kadın için hayatı boyunca sanatına sığındığını görürüz. Peyami Safa'nın Bir Tereddüdün Romanı'nda da muharrir olan başkişinin hayatını ve sanatını, Mualla ve Vildan arasında kalmanın yarattı̆̆ "tereddüt" şekillendirir. Bu ve buna benzer örneklerde eserlerin hep erkek egemen bir bakış açısıyla kadının kimi zaman bir ilham kaynağı, kimi zaman da aşılması gereken bir figür olarak çizildiğini görmekteyiz. Kanaatimce bu konuda yazarı ve başkişisi bir kadın sanatkâr olan eserlere de bakmak önemli olacaktır. Konumuz açısından en tipik eserlerden biri, sanat ile kadın arasındaki ilişkiye odaklanan ve edebiyatın resim sanatıyla ilişkisi açısından da farklı perspektifler sunan Halide Edip'in Son Eseri romanıdır.
Anahtar Kelimeler

Künstler Roman

Erkek Yazar

Kadın Yazar

Kadın

\section{Makale Hakkında}

Geliş Tarihi: 09.09.2020

Kabul Tarihi: 26.03.2021

Doi: 10.18026/cbayarsos.792881

\section{The Function of Women in the Creation Process of Art}

\section{Abstract}

In novels and stories where the main character is a writer / poet man, we see that female characters are constructed in a very functional way in the creation process of the work of art. In Mai and Siyah of Halit Ziya Uşakligil, one of the most competent first examples of the Turkish novel, meeting with Lamia, together with being a famous poet and having a printing house is one of three dreams of Ahmet Cemil. As Tanpinar mentioned, Lamia is not a simple love, but a symbol of the lifestyle and welfare level that Ahmet Cemil wants to achieve (all of which depends on being a good poet). While Tanpınar depicts Nuran's role played in the life of the academician-poet Mumtaz in his novel Huzur, it seems that he wants to make Ahmet Cemil's dream to be real to some extent. In Yakup Kadri's "Rahmet" story, the lead person is a character who is a male writer. Rejecting the world of the woman he loves and moving away from her play a very important role for this character to adopt a literary understanding that tells about the suffering of the society and the nation. In the story of Sabahattin Ali's "Kurtarılamayan Şaheser", we see that the process of creating an ideal and original work is directed and even finalized by a female character step by step. In the "Viyolensel" story of the same writer, we see that a musician, although not a poet and writer, took refuge in his art throughout his life. In Peyami Safa's Novel Bir Tereddüdün Romanı, the "hesitation" caused by being between Mualla and Vildan shapes the life and art of the writer person. In this kind of works, we see that the works are always written from a male-dominated perspective sometimes as a source of inspiration and sometimes as a figure that must be overcome. In my opinion, it will be important to look at the works whose author and/or character is a female person. One of the most typical works in terms of our topic is Halide Edip's novel Son Eseri, which focuses on the relationship between art and women and presents different perspectives in terms of the relationship between literature and painting art.
Keywords

Künstler Roman

Male Writer

Woman Writer

Woman

About Article

Received: 09.09.2020

Accepted: 26.03.2021

Doi: 10.18026/cbayarsos.792881

a Doç. Dr., Manisa Celal Bayar Üniversitesi, Fen-Edebiyat Fakültesi Türk Dili ve Edebiyatı Bölümü - https://orcid.org/0000-0001-9935-0569 


\section{Giriş}

Baş kişisi yazar/şair olan ve bir sanat dalının ve eserinin oluşumuna odaklanan bazı roman ve hikâyelerde, eserin içinde ve oluşturulma sürecinde kadın karakterlerin oldukça işlevsel bir şekilde kurgulandıklarını görürüz. Dolayısıyla üzerinde duracağımız eserler, roman/hikâye söz konusu olduğunda "sanatçı romanı" yani künstler roman olacaktır. Künstler roman, Entwicklungsroman (gelişim romanı) ve Erziehungsroman (eğitim romanı)la birlikte Bildungsromanın'ın (Huyugüzel, 2018, s.86-88) üç alt türünden biridir. Konumuz "kadın” karakterlerin karakterize edilme meselesi olunca, yazanın erkek veya kadın olması da önemli bir husus olarak karşımıza çıkmaktadır.

Sanat eserinin yaratılma sürecindeki en önemli unsurlardan biri "kadın"dır. Gerek Batı'da gerekse Doğu'da sanatı üreten genelde "erkek" olarak tasavvur edilmiş, "kadın" bu yaratma sürecinin nesnesi veya ilham kaynağı olarak görülmüştür. Modern Türk şiirinin en radikal denemelerini yapan Hâmid'in eserlerinin ana temalarından biri "kadın"dır. Kadınlarla olan ilişkileri bağlamında hayli renkli ve hareketli diyebileceğimiz şahsî hayatıyla da dikkat çeken Hâmid'in antik dönemin Asur krallarından hedonist Sardanapal'ın hayatından esinlenerek yazdığ tiyatrosunda "kadın", genel anlamda hayatın esas kaynağı, sebebi olarak tasvir edilir. Hayli uzun olan bu tasvirden sadece konumuzla ilgili kısımları alıntıladık: (Tarhan, 2000, s.226-227)

Kadınlarsınız siz, güzellersiniz;
Ne söylerseniz, rûha söylersiniz.
Bedâ'yisiniz bunda zâtu's-sıfat;
Sizinle eder Hak bize iltifat.
Hudâ vermiş elhak meziyyet size;
Denîdir verenler eziyyet size!..
Sizin sun'unuzdur bütün şairân;
Sizin feyzinizle olur hâme-rân.
Bu üryan mehâsin, bu sâfi beden,
Daha sûd-bahşa durur şiirden!..
Sizin ilmi sanidir âlâtınz;
Beraber doğar hep kemâlâtınız.

Görüleceği üzere, "güzellik, estetik, sanat", kadına ait sıfatlardır, bunların sahibi "kadın"dır, hatta Allah'ın erkeklere iltifat sebebidir. Bütün şairler kadının eseridir. Yazarlar kadınların verdiği ilhamla ellerine kalemlerini alırlar. Bütün bunların ötesinde kadın, bizzat estetiğin kendisidir. Kadının yaratma sürecinde bir ilham kaynağ1 olarak görülmesi, şiirin estetik planına Tanzimat şairlerinden daha çok yönelen Servet-i Fünuncularda, söz gelimi Tevfik Fikret'in "Ey Kız", "Peri-i Şiirime”, "La Danse Serpantine" gibi eserlerinde daha belirgin bir hâl alır. Buna benzer şiir örneklerini edebiyat tarihimizin diğer dönemlerinde de görebilmek mümkündür. Biz burada daha çok hikâye ve roman örneklerine yöneleceğiz. 


\section{Yöntem}

$\mathrm{Bu}$ makalede konuyla ilgili eserler, çalışmalar ilgili sitelerden (Kütüphaneler, Google Akademi, Yök Tez vs.) taranmıştır.

\section{Araştırma Modeli}

Tartışma, Mukayese, Sentez, Örnekleme, Tümevarım, Tümdengelim, Tahlil ve Değerlendirme

\section{Bulgular, Tartışma}

Sami Paşazade Sezai'nin Sergüzeşt'inde ressam Celal'e resimlerinde model olan Dilber'dir. "Pandomima" hikâyesindeki Pascal'ın sahnede hayat bulmasına ve hayatını yine sahnede sonlandırmasına vesile ve sebep olan Rum güzel Eftelya'dır. Sezai'den sonra" Halit Ziya, eserlerinde sanatı ve sanatçıyı konu edinmesi bakımından üzerinde durulması gereken bir isimdir. İzmir döneminde yazdığı romanların en yetkin örneği diyebileceğimiz Bir Ölünün Defteri'nde (2017) Osman Vecdi, hekimliği tercih ederken Galatasaray'dan arkadaşı Hüsam, Nesim-i Havadis'e şair/muharrir olur.

Osman Vecdi, annesi ve babasını kaybedip büsbütün yalnız kaldıktan sonra halası ve kuzeni Nigâr ile Beylebeyi'ndeki yalıda yaşamaya başlamıştır. Tatil günleri Hüsam'1 da evlerine davet eder. Halit Ziya'nın diğer eserlerinde gördüğümüz ve Servet-i Fünun romanının karakteristik bir özelliği olan üç kişi arasında yaşanan aşkın ortaya çıkması için gerekli zemin de böylece hazırlanmış olur. Aslında halasının Nigâr'la kendisinin evlenmesini arzulamasına rağmen Osman Vecdi, Nigâr'la Hüsam'ın birbirlerine yakınlaşmalarını fark eder ve acı çekerek aradan çekilir. Hüsam'ın şairliğe yönelmesi Nigâr'ı mütalaaya daha çok yöneltir. Osman Vecdi Nigar'ın bu ilgisini farketmesi üzerine ona fennî ve edebî dergiler alır. Kızın bunlardan edebî olanlara ve hikâyeden ziyade bilhassa şiire yönelmesi dikkatini çeker. Kendisi de şiiri çok sevdiği hâlde, şiirin fikri zehirlediğini iddia eder. Nigâr ise buna şöyle itiraz eder:

"Şiiri daima menfur görüyorsun. Ben de aksine insan yaşamak için fikrine bir parça şiir karıştırmalıdır, itikadındayım. Şiirsiz fikir, renksiz çiçeğe benzer. Senin şiiri sevmediğine ihtimal veremem. Bilmem niçin bana kendini öyle göstermek istiyorsun. Şiiri sevmemekte imkân aramak için gurubun hüznünü, fecrin neşvesini, semanın lacivert rengini, bütün tabiatın bedialarını anlamayacak, bütün bu ulvi şeylere karşı kayıtsız kalacak bir tabiat tasavvur edebilmelidir. Sen öyle olmadığın gibi beni de öyle görmek istemezsin zannederim." (s.68-69)

Osman Vecdi, şair Hüsam'ın kendi meslek tercihiyle alay edişine Nigâr'ın da tasdik etmesine çok içerlemiştir. Aslında şiiri çok sevmesine ve Nigâr'ı da haklı bulmasına rağmen, düşündüklerinin tam tersi hareket etmesinin sebebi, Nigâr'la Hüsam'ın yakınlaşmalarının bir nebze de olsa intikamını almaktır. Roman, Hüsam'ın ölüm döşeğindeki Osman Vecdi'nin hatıra defterini okuması üzerine kurgulanmıştır. Ancak asıl şair mizaçlı Hüsam değil, defterin sahibi, dolayısıyla romanın benanlatıcısı Osman Vecdi'dir. Hüsam'ın muharrirliği tabiatı gereği değil, kendisine bir 
meslek seçemeyişinden ve tam ne yapacağını düşünürken kendisine gelen bir mektuptan dolayıdır. Mektupta Hüsam'ın “iktidarından, kemalinden, zekâ ve irfanından" bahsedilmektedir. Ekonomik bakımdan ailesinin desteği de kesilen Hüsam hevesle muharrirle başlar. Dergide yayımladığ 1 “Terane-i Seher" başlıklı şiiri Nigâr da okumuştur. Her ne kadar Hüsam bir sanatkâr mizacına sahip olmasa bile onun şairliği/yazarlığı bir meslek olarak seçmesinde Nigâr'ın etkisi büyüktür. Nigâr bir kadın olarak Hüsam'ın eserini yaratma eyleminde bir ilham kaynağı değildir ancak yönlendirici bir işleve sahiptir.

Halit Ziya, sanatçı, sanat ve kadın ilişkisini en yetkin bir şekilde Mai ve Siyah'ta (2016) işlemiştir. Ahmet Cemil'in üç büyük hayali vardır: Meşhur bir şair ve matbaa sahibi olmak ve en yakın arkadaşı Hüseyin Nazmi'nin kız kardeşi Lamia'yla evlenmek. Tanpınar'ın da bahsettiği gibi Lamia, sade bir sevgili değil Ahmet Cemil'in ulaşmak istediği hayat tarzı ve refah seviyesinin (Bunların hepsi iyi bir şair olmaya bağlıdır) bir sembolüdür.

Edebiyat tarihimizde sanat ve estetik seviye bakımından yetkin ve gelişmiş bir dönemi temsil eden Servet-i Fünun'un romanı olarak değerlendirilen Mai ve Siyah'ta Ahmet Cemil ve Hüseyin Nazmi, aynı mektepten mezun olmuş iki samimi arkadaştır. Okumaya düşkünlük ikisinin ortak yönlerini oluşturur. Okumaya önce Divan'lar ve tarih kitaplarıyla başlamakla birlikte kendilerini Batılı sanatçllarda ve eserlerinde bulurlar. Ancak sanata ve şiire yönelen ve onu hayatının gayesi haline getiren Ahmet Cemil olur. Ne yazık ki ailesinin geçimini üstlenmek zorunda kalması, çok sevdiği edebiyatla uğraşmasına engel haline gelir. Bununla birlikte yayımlamak üzere bir şiir defteri hazırlamayı başarır. Hayata, tabiata tıpkı Servet-i Fünun sanatçları gibi estetik ve aynı zamanda marazî bir cepheden bakma Ahmet Cemil'de de vardır. O, edebiyat teorisindeki sınıflandırmayla hem "emekçi" hem de "cezbeli" bir sanatçıdır.

Konumuz açısından Ahmet Cemil'e bakacak olursak, onun hayatında etkili olan kadınları şöyle sayabiliriz: Annesi Sabiha Hanım ve kızkardeşi İkbal, hizmetçileri Seher, Raci'nin çilekeş eşi, nadiren gittiği Beyoğlu'nun eğlence âlemlerindeki yabancı kadınlar ve arkadaşı Hüseyin Nazmi'nin kız kardeşi Lamia. Annesi ve kız kardeşi, onun için ailedeki sevgi, fedakârlık ve dayanışmanın timsalidirler. Onlara hizmetçileri Seher'i de ilave edebiliriz. Kız kardeşi İkbal, Seher ve Raci'nin eşi ise toplumun ve erkeklerin mağdur ettiği, şiddette maruz bıraktığı kadınların sembolü olarak karşımıza çıkarlar. Beyoğlu'ndaki eğlence hayatının malzemesi olan kadınlar, bu sefih hayata sürüklenmek zorunda kalmaları itibarıyla Ahmet Cemil'e göre toplumun bir başka kanayan yarasıdır. Hayata estetik bir gözle bakan şair ruhlu Ahmet Cemil'in ilham kaynağı olan kadın ise Lamia'dır.

Lamia'dan önce onun hayallerini süsleyen "bir genç kız"ın imaj olarak da olsa varlığ1 önemlidir. Bir matbaaya sahip olma hayallerinin arasına belli belirsiz de olsa başka bir hayal daha karışır:

“Bütün bu mütebessim hülyaların arasına bir hayal de girerdi, fakat bu hayal pek seyyal idi, belli belirsiz bir şey.

Müphem bir çocuk çehresi, kim bilir kimdir? Ahmet Cemil bu çehrenin ismini bilmekle beraber sarahatle bile tayine cesaret edemezdi." (s.75)

Hüseyin Nazmi'lerin Erenköy'deki köşklerinde kaldığı ve Lamia'nın da piyano çaldığı bir gece, bu müphem varlığa kavuşma arzusu iyice ortaya çıkar. Bahsi geçen küçük konser, 
Erenköy'deki köşkü sarmalayan tabiat güzellikleri ve gizemli gece, son derece sanatkârane çizilmiş empresyonist bir tablo oluştururlar. Lamia, o zamanlarda bile Ahmet Cemil için "mücessem şiir" gibidir. Ancak onu dile dökmekten çekinir, mehtaplı bir gecede "genç kız"la ilgili hayallerini, duygularını tahlil ederken zaman zaman bulutların arkasından çıkarak mehtap, "hakikat"ın "sırıtıan" yüzü olur. (s.119)

Hatta Raci'nin şiddet mağduru hanımı bile "rakik" şair Ahmet Cemil'e "feryat eden şiirin hüznü" gibi gelir (s.94). Dolayısıyla şiir, bir edebî türe isim olmanın dışında yazarın diğer eserlerinde de estetik bir sıfat olarak kullanılır. Ahmet Cemil, Lamia'nın bir genç kız olduğunun farkına varmadan önce de muhayyilesindeki genç kız tasavvur ve özlemini son derece estetik bir şekilde tasvir eder. Bu tahayyülünü Hüseyin Nazmi'lerin köşkünde kaldığ bir mehtaplı bir gecede canlandırması bir tesadüf değildir.

Gece köşkün bahçesinden dişarıya çıktığında mehtap, tabiata bir "aşk firaşı" hazırlamak üzeredir:

“Ah o genç kız! Ona ne vakit tesadüf edecek?.. Kimindir o küçük seyyal sima ki hülyasının aynası üzerinden zapt edilemeyen bir renkle güya bir bulut parçası altında mütemevviç, akıp gidiyor?

O genç kız ki tanımıyor, bilmiyor, görmemiş, vücudundan vuzuhla haberi yok, fakat seviyor, bütün gençliğin sevdadan mahrum geçen ihtiyacıyla, bütün aşk kabiliyetinin hasretiyle seviyor. Onun ayaklarına atılmak, başını dizerine koymak, gözlerini bir rüyanın şiirinde kaybolarak gözlerine dikmek, ellerini bütün hayatının bir teslimiyet hücceti gibi ellerine terk etmek, sonra hazin fakat bahtiyar, gönlü kırık mesut, yavaş yavaş, katre katre sıcak yaşlarla ağlamak isterdi.

Şimdi ay küçük beyaz bulutların, öbür tarafında yığılmış küme küme beyaz atlasların arasında, sanki yatağında gecikerek baygın bir sevda nigâhıyla:

"Evet, şair efendi, o genç kız.." diyordu; sonra çirkin, hani bir tebessüm açılıyor, açılıyor, bu bir muammayı andıran simayı bir yandan bir yana kaplıyordu; "Evet, şair efendi, o genç kız..." Bu çehre siritıyor, acı bir istihza ile daima siritıordu...

Artık ona bakmamak, hülyalarının şaşaasına o hazin sarı ziyasını serpen bu müstehzi simadan gözlerini ayırmak istiyordu." (s.119).

Ahmet Cemil bir taraftan ailesinin geçimini sağlamak için çalışırken bir taraftan da eserini bitirmek için uğraşır. Matbaanın yoğun iş yükü arasında bir haftasını eserine ayırır, bazı düzenlemeler yapar. Bir mayıs günü matbaadan çıkarak, talebeliklerinde Hüseyin Nazmi'yle şiirler okudukları Taksim Bahçesi'ne gitmeye karar verir. Tünel'den Taksim'e çıkarken Beyoğlu'nda Bonmarche'de Lamia'yla karşılaşır. Bu karşılaşma, zaten şahsiyeti üzerinde derin bir etkisi olan genç kız hayalini cisme kavuşturmuş olur. Lamia'nın ağabeyiyle birlikte kendisinin de şiiri dinlemek ve okurken Ahmet Cemil'i görmek istediğini söylemesi, ancak bunu zaptetmeye çalıştığı küçük bir kahkahayla söylemesi, Ahmet Cemil'i âdeta kanatlandırır.

Burada da "genç kız", Ahmet Cemil'in sanatını ve estetik düşüncesini besleyen bir ilham kaynağı olarak tasvir edilir. "Genç kız" sıfatının onun zihninde zaten hususi ve müstesna bir ehemmiyeti vardır. Bu muhayyilenin Lamia'yla somutlaştırılması romanın bu kısmında da tekrar edilir. Kıyafeti ve elindeki şemsiyesiyle, son derece estetik bir obje olarak tasvir edilen genç kız, Batı edebiyat ve sanatındaki örneklerini hatırlatır:

“Ahmet Cemil'in zihninde bu genç kız sıfatının hususi ve müstesna bir ehemmiyeti vardı. $O$, henüz çocukluktan çıkarak mevcudiyeti garaible memlu bir cihanın esranına karşı inkişafa müheyya duran, nagihan hissediverdikleri bir hakikatin taaccüp rengi gözlerinde sizi istintak ediyormuşçasına bir istifsar ifadesiyle uçuşan, bazen çocukluktan kalmış bir itiyat bakiyesiyle gülüverirken birden bire bir 
genç kız sıfatının henüz itilaf olunamamış ciddiyetiyle gözlerini indiren, dün başka bir şeyken yarın başka bir şey olmaya hazırlanan; fakat bugün müphem, müşevveş, o müphemiyeti, müşevveşiyeti için şiirle, sevdayla dolu olan o mahluklara, bütün güzergâhına tesadüf eden o genç kızlara Ahmet Cemil perestişe benzer, buseyi andırır bir garam nazarıla bakardı.

Kalbinde yer tutmuş böyle binlerce çehreler vardı. Köprü'den vapura binerken gördüğü vapura binerken gördüğü yahut Şişli'deki bir Kağıthane dönüşünde tesadüf ettiği yahut Tepebaşı'nda, Taksim'de, Köprü'de hemen her yerde bir dakika için sevdiği binlerce çehreler vardı ki bunlar kendisi için saadet hülyası olan o genç kızın mevhum şekli etrafında uçuşan birtakım periler, kanatlı şiirlerdi. Bunların hepsini severdi, dha doğrusu o genç kıza bunların her birinde ayrı ayrı perestij ederdi, fakat bütün bu çehrelerin üstünde, bütün bu mütebessim hülyaların arasına bir hayal de girerdi. Bu hayal pek seyyaldi, belli belirsiz bir şey! Müphem bir çocuk çehresi, "Kim bilir kimdir?" diye aratacak bir sima?..

Bugün Lamia'yı karşısında siyah çarşafı çenesinin altından tepesi bir incili iğneyle iliştirilmiş, peçesi alnının kıvırcık saçlarını bir yarı örtülülük altında bırakarak başına atılmış, ince parmakları siyah güderi eldivenler içinde uzun saplı zarif şemsiyesinin püskülünü oynatarak; henüz çocukluğunu unutmamış, henüz iki üç sene evvelki sıfatıyla Ahmet Cemil'in karşısında bulunuyormuş gibi saf çehresiyle bakarak görünce, zihninre uçuşan o binlerce çehreler- bir ziya isabetiyle bir bulut parçasında peyda oluverip de birden sönüveren iltimalar gibi- uçtu. Sonra onların arasında genç kız, o gençliği semasının sevda güneşi, nurlarını serperek, cazibesinin ateşlerini saçarak çıktı..." (s.161-162)

Mai ve Siyah'ta (1896) genç kızın estetik bir varlık ve bir ilham kaynağ bizlere Tevfik Fikret'in 1893'te Hazine Fünun'da yayımlanan (Kaplan, 1987, s.93) ve şiirde monoton ahengi kırmak için yaptığ1 değişiklikleri içeren "Ey Kız" şiirindeki (Tevfik Fikret, 2017, s.288) misraları hatırlatmaktadır:

Vaz-1 meâl-perverinle eş'ârdan güzel;

Şair değil, fakat ne kadar şârinesin!

Sâfiyyet-i muhabbete ezhârdan güzel

Bir nişânesin.

Lamia'ya tesadüfün peşi sıra Ahmet Cemil'in muhayyilesini eserini Lamia'ya nasıl okuyacağıyla ilgili hayaller işgal etmeye başlar :

“Gece yalnız kaldığı vakit zihninde yalnız iki şey yaşıyordu: Eseriyle Lamia. Bu iki emel hedefi bir çift tev'em hemşire gibi hatırasında öpüşüyordu. Lamia'yı düşünürken eserini, eserine fikrini sevk ettikçe o siyah gözlerin “Bitirsenize. Ben de dinlemek isterdim!" manasıyla gülümsediğini görüyordu.

Bu gece uykusunun arasında hep o eserle o hayal yaşadı, sabahleyin kendi kendisine "Evet artık bitirmeliyim!" dedi." (s. 182-183).

Romanda evi ipotek ederek eniştesiyle matbaaya yeni makineler almak ve hevesle eseri bitirmeye gayret etmek Ahmet Cemil'i en bahtiyar eden hususlardır. Eseri bitirme ve onu Lamia'ya bir zevc olarak takdim etme arzusu hep bir hayalin arzusu olarak eserde çeşitli şekillerde tekrar edilir (s.196-197).

"Artık endişe edecek bir sebep göremiyordu, bütün emellerinin husulüne bir iki hatve kalmıştı: Eseriyle aşk1..." (s.198)

Hüseyin Nazmi'lerin köşkünde edebiyatla meşgul arkadaşların huzurunda eserini çevresindekilere okuduğu gün Lamia'nın da dinlediğini fark etmesi, Ahmet Cemil'in 
muhayyilesinde lirik, heyecanlı ve duygusal tasavvurlara yol açar. Bunları ifade ettiği kısımlar, eserine Lamia'nın nasıl bir lham kaynağı olduğunun da göstergesidir:

“Ah! Şimdi aşkını haykırmak ihtiyacı dudaklarını yakıyor, yüreğinden bir şey şişerek bütün duyduklarını onun dizlerinin dibinde can çekişiyormuşçasına sürüne sürüne dökmek istiyordu. Evet, hepsini söylemek, "Sizi seviyorum" demek, "Ah! Bilseniz ne kadar seviyorum! O demin kapının arasında dinlediğiniz eseri yazmak için, onun her kelimesini bulmak için sizi düşündüğümü; onu sizin ayaklarınızın altına serip yaymak için yazdığımı, biliyorsunuz değil mi? Bütün hayatımda ruhuma hülyanızla daimi bir eş olduğunuzu, bir şey, rüyanıza tesadüf etmiş bir hayal, pencerenizden girmiş bir bahar havası size hissettirmedi mi? Bırakın, şurada gözlerinizin altında öleyim.." demek, bütün senelerden beri zapt olunmuş feryatları, kendisini kaybederek söyledikçe mest olarak, tatlı bir ölümle olanca maneviyeti eriyerek dökmek istedi." (s.211).

Lamia'nın defterin sonuna düştüğü "Tebrik ederim" daha sonra beş sıfır, yani beş nokta" notu Ahmet Cemil'in hayallerini daha da kanatlandıran bir gelişme olur (s.215). Ancak bilindiği üzere bu hayaller hakikatin haşin cephesiyle karşılaştıkça bir bir sukuta uğrayacaktır. Romanın ilk sahnelerinde "ay"ın "sırıtması boşuna değildir. Önce kız kardeşi İkbal, eniştesi Vehbi'nin şiddetine ve hakaretlerine dayanamayarak hem çocuğunu düşürecek hem de hayatını kaybedecektir. Böylece Ahmet Cemil iş hayatının en mutlu hayallerini barındıran ve çalışmaktan büyük zevk aldığı matbaadan da uzaklaşmış olacaktır. Bütün bunlardan sonra "Lamia"ya ve "eser"ine sığınmak ister (s.234, s.245). Ancak Hüseyin Nazmi'nin "Senin küçük Lamia'yı veriyoruz.." (s.285) haberiyle onu da kaybetmiş olacak, "ölmüş bir çocuğun boş ve soğuk bir gömleği"ne benzettiği eserini, artık bir manasının kalmadığını düşünerek, sobasında yakacaktır (s.304-305). Ateşe attığ1 aslında kendisini hayatın hakikatlerinden uzaklaştıran hayalleridir.

Bir sanat eserinin ateşte yakılarak yok edilmesi motifine Sabahattin Ali'nin 1929'da yazdığ 1 ve 1932'de Atsız Mecmuası'nda yayımladığı "Kurtarılamayan Şaheser"( 2015) hikâyesinde rastlarız. Bu eserde de ideal ve özgün bir eserin yaratılma ve hatta yok edilme sürecini adım adım bir kadın karakterin yönlendirdiğini ve hatta neticelendirdiğini görürüz. Genç bir şaire sevgilisi, ancak "herkesten yüksek şeyler yaratırsa seveceği"ni söylemiştir. $O$ da şaheserini tamamlayarak sevgilisine gönderir.

Memleketin bütün kadınları genç şairin şiirlerini "sonsuz bir baygınlık ve şehvet"le okumaktadırlar. Ancak sadece çok güzel bir genç kız onu hafife almaktadır. Şair de eserleri karşısında kendinden geçmeyen bu genç kızı sevmektedir. Genç kız, şairden "tanımadığı şeylerden, saklı güzellikler ve hakikatler"den bahsetmesini ve bunları herkesten daha güzel yazacak bir kudrete sahip olmasını ister. Onun Fuzulî gibi derin, Goethe gibi azametli olmasını, ihtiras ve çllgınlıkta Shakespeare'i; istihza ve ıstırapta Dante'yi geçmesini ister. Genç, bir ay ormanlarda dolaşır, nehirleri, çiçekleri ve sevimli hayvanlarıyla tabiatın içindeki güzelliklerin ve şehrin içindeki gizli sevdaların kendi zihnindeki romantik izdüşümlerini gümüş bir kalemle gümüş kaplı bir deftere yazar ve onu sevgiline yollar. Ancak sevgilisi, sadece çiftlik sahiplerinin kızlarını ve ev hanımlarını mutlu edecek bu şiirlerinin Horatius'unkiler kadar tesirli ve tatlı, Vergilius'unkiler kadar temiz olmadıklarını iddia ederek beğenmez. Aslında genç kızın bu Romalı şairleri zikrederek iletmek istediği mesaj, romantik duyuşları içeren lirik ve pastoral, epik şiir geleneğine uyarak yazmanın moda olmaktan çıtığıdır (s.27). 
Genç şair bu sefer, altı ay memleketin bütün büyük filozof ve şairlerini dolaşır. Ancak bu şairlerin hiçbirinin yazdıklarıyla yaşadıkları birbirini tutmamaktadır. "Ruhun ölmezliğì", "ezelî ve felsefî hayat", dünya hayatı ve zevklerinin süflîliğinden bahseden şairler hayatı bütün zevkiyle yaşamakta; estetik, sanat ve şiirin verdiği zevke kumar zevkini tercih etmekteler; bir kadın naifliğine sahip salon şairleri, şiirlerini zalim ve gösteriş düşkünü sultanlar için yazarken saz şairleri de halkın içinden çıktıkları hâlde halkın acılarına yabancı kalmaktadırlar. Genç şair bu gözlemlerini, bu sefer altın bir kalemle altın ciltli bir deftere geçirdiği şiirleri sevgilisine yollar. Ancak sevgilisi yine Eflatun'un, Homeros'un ve Firdevsî'nin kendisinden çok daha usta olduğunu belirtir.

Genç şair, üçüncü denemesinde kendini çöllere ve şimalin buzlu sahralarına vurur ve yalnızlık ve sonsuzluk içinde mutlak hakikatin sırrına ulaşmak ister. Bu sırada rastladığı bütün ahlak ve namus münakaşalarının masum ve zavallı insanların hayatlarını mahvetmek üzere düzenlendiğini fark eder. İlahî bir bilgeliğe eriştiğini düşünür ve bu sefer izlenimlerini siyah bir kalemle siyah ciltli bir meşin defterde şiire dönüştürür. Genç sevgilisi peygamberlerin bile gıpta ettiği bu aşamada çok mutlu olur ve bütün bunları kendisi için yapan şair sevgilisine teşekkür eder. Kendini bütün kadınlardan şanslı ve üstün hisseder. Ancak kendi yazdıklarına duyduğu hayranlıkla genç şair, sevgilisini hiç işitmez. Buna öfkelenen genç kız, şaheseri ateşe atar. Ardından aralarında bir boğuşma yaşanır. Genç şair, hayatının gayesi olan kadını da boğazını sıkarak öldürür, kendisi de cansız yanına yuvarlanir.

Kanaatimizce bu hikâye konumuz açısından hayli önemlidir: Öncelikle sanatçının erkek, kadının sanat eserinin yaratılmasında bir ilham kaynağı ve motive edici güç olduğu tezini tekrarlamaktadır. Buna göre "kadın", vasıtalığını tamamladıktan sonra "erkek" yazar için işlevini yitirmekte, onun yerini sanatçının narsist duyguları almaktadır. Ancak Sabahattin Ali, "kadın"1, bu geleneksel ilham kaynağı olarak görülmesine karşı çıkan bir figür şeklinde kurgulayarak ferdin özgürlüğüne vurgu yapmak ister.

Sabahattin Ali'nin "Viyolensel" hikâyesi ile (Sabahattin Ali, 2015, s.42-50) Kürk Mantalu Madonna'sından (Sabahattin Ali, 2004) da kısaca bahsetmek gerekir. “Viyolensel” de bir şair ve yazar olmamakla birlikte bir müzisyenin sevdiği kadın için hayatı boyunca sanatına sığındığını görürüz. Kürk Mantalu Madonna'nın Raif Beyi mütercimdir ve resimden iyi anlar ve zaman zaman duygularını resim vasıtasıyla da ifade eder. Dışarıdan çok içine kapanık ve hayli pasif bir insan olarak görülen Raif Beyin ne denli hisli, içli ve estetik hassasiyetleri zengin bir dünyaya sahip olduğu, aynı odayı paylaştığı mesai arkadaşı vasıtasıyla ortaya çıkar. Dolayısıyla roman mizaçları birbirine çok benzeyen ben anlatıcının Raif Beyle tanışmalarını anlatan bir çerçeve hikâye ile Raif Beyin defterinden oluşmuş gibi kurgulanmıştır. Hem ben- anlatıcı hem Raif Bey, muhitlerinin sathî ilişkilerine ve insanlarına ayak uyduramayıp edebiyata ve sanata sığınmaktadırlar. Ben-anlatıcının ölmek üzere olan Raif Beyin çekmecesinde bulduğu defter, bir günde kaleme alınmıştır. Raif Beyi yazmaya iten, ilk başta Almanya'dayken pansiyonunda kaldığı Frau von Tiedemann (Döppke) ve yanındaki küçük kızla karşılaşması neticesinde öğrendikleri olur. Berlin'deyken gezmekten büyük zevk aldığı sanat galerilerinden birinde gördüğü bir kadın portresi onu çok etkilemiş, ardından portrenin sahibi Maria Puder'le, hayatının en anlamlı vakitlerini geçirmiştir. Raif Bey tabloyu ilk gördüğü andan itibaren çok etkilenir ve tablo onu çocukluğundan beri çok okuduğu romanların, tarih kitaplarının kadın karakterlerine, dinlediği mevlidlerdeki Amine Hatun'a götürür(s.56-57). Almanya'ya zeytinlik ve fabrika sahibi babası tarafından sabun 
imalatındaki yeniliklerini öğrenmek üzere gönderilen ancak işinin peşine düşmek yerine vaktini sana galerilerinde, müzelerde geçiren 24 yaşındaki Raif Beyin olabildiğince naif, "kadınsı" dünyasında fizikî anlamda "kadın" hiç yer almamıştır:

"Kadın, benim için, muhayyilemi kamçılayan, sıcak yaz günlerinde zeytin ağaçlarının altına uzandığım zaman yaşadığım bin bir türlü maceraya iştirak eden, maddîlikten uzak, yaklaşılmaz bir mahluktu." (s.60)

Onlarla muhayyilesinde en uçarı yolculuklar yaptığı halde gerçek hayatta bir kadından, annesi de dahil, hep uzak durmuştur. Ancak sergiye kendini çizdiği portresiyle katılan kürk mantolu Maria Puder, Raif Beyi hayatında tek anlayan kadın, hatta tek insandır. Çerçeve hikâyenin ben-anlatıcısı, ancak son gününde onu gerçek anlamda tanıyabilir. Dolayısıyla Maria Puder, Raif Beyin hem şahsî hayatının hem de yazma serüveninin biricik kahramanıdır. Frau Döppke'nin yanında gördüğü kızın, ondan kalan tek yadigâr olduğunu fark ettiğinde çok geçtir. Sabahattin Ali'nin bu eserinde kadın figürü, "taibat"la birlikte, erkeğin her anlamda hayatını değiştiren, ona yön veren, sanatçı kabiliyetini ortaya çıkaran "anima arşetipi" fonksiyonundadır. Raif Beyin en büyük sığınağı, Havran ve Berlin'in eşsiz tabiat güzellikleri ile sanat galerileri, müzeler ve klasik müziktir. Bu iki sığınak, "tabiat" ve "sanat", ancak gerçek anlamda kendisini anlayan bir "kadın"la mana kazanır. "Kadın"1 kaybettiğinde, onlar da, hatta "hayat" 1 da manasını yitirir, etrafına da yabancılaşarak “lüzumsuz bir adam”a (s.127) dönüşür. Ancak onu var eden defterine yazdıkları, yani sanatı olur.

Halit Ziya'nın Ahmet Cemil'i, Sabahattin Ali'nin Raif Efendi'si gibi estetik duyguları zengin sanatçı ve şair ruhlu olmakla birlikte hayata yabancı, aşırı hissî hatta "kadınsı" erkek karakterleriyle dikkat çeken ve eserlerinde yaratma sürecine de yer veren bir başka yazar Tanpınar'dır. "Kadın"ın Tanpınar'ın eserlerinde hem "haz" hem de bir "günah" kaynağı olarak yer alması, başta Mehmet Kaplan olmak üzere birçok araştırmacı tarafından değerlendirilmiştir (Kaplan, 1987, s.361-425; Çağın, 2010, s.261-275; Şahin, 2012). Huzur"da hayata bir sanatçı perspektifinden bakan akademisyen Mümtaz, tezinin yanı sıra Şeyh Galip üzerine bir roman üzerinde de çalışmaktadır. O, Nuran'ı kendi şair ruhuna hitap ettiği, estetik bakış açısının şekillendirdiği bir hayat anlayışına sahip olduğu için sevmiştir. Tanpınar, şair ruhlu akademisyen Mümtaz'ın hayatında Nuran'ın oynadığı rolü tasvir ederken kendi eserinde, çok sevdiği roman kişisi Ahmet Cemil'i bir nebze de olsa hayallerine kavuşturmak ister gibidir. Tıpkı Ahmet Cemil gibi Mümtaz'ın da tahayyülünde sanatkârane bir aşk zaten vardır. Kimi zaman çok sevdiği İstanbul'la sevdiği kadını ancak Nuran gibi bir kadını ayırd edememesi, hep hayata estetik bir pencereden bakmasının neticesidir. Nitekim, Nuran'ın eski kocasılla barışması üzerine bütün hayatı gibi eseri de yarım kalmıştır. İstanbul da Nuran'la birlikte olduğu zamanlardaki manasını kaybetmiştir.

Aydaki Kadın'daki (Tanpınar, 1987) Selim de Çöküntü, İflas başlıklı bir roman üzerinde çalışmaktadır. Onu ilk yazmaya iten, yaşça kendisinden büyük ve yakınlık hissettiği Atıfe'nin otuz dokuz kırk yaşlarındaki annesi Zümrüt Hanımla yaşadığı ilk ten zevkinden duyduğu suçluluk ve günah duygusudur. Zümrüt Hanım, Selim'i “birden 
bire bir örümcek gibi yakalamış, küçük, şaşırtıcı birkaç darbede sersemletmiş, kendi avı yapmıştır." (s.50). Selim'e romantizm aşılamak bir tarafa tam tersine onu öldüren Zümrüt Hanım, "ne psikoloji kitaplarının nymphoman diye adlandırdığı, ne romantizmin girdiği yeri yakıp kül eden meşum kadınlardandır". Selim'in kendisi için yazdığ 1 "ateşli şiir"i okuduğunda sonuna kadar sessizce dinlemiş sonra "Vaz geç böyle şeylerden... Mecbur değilsin..." diyerek yırtar (s.50-51). Arkadaşları Faik, Ziya, Nuri, Asım, Refik'le ileride hangi meslekleri seçeceklerine dair konuşurlarken Selim, işlediği günahın utancı ve azabı içinde, hiçbir şey söylemez. Faik ve Refik'in sorusuna önce "Hiçbir şey" diyerek cevap verir, ardından hem biyolojiye hem de edebiyat ve tarihe meraklı olduğunu söyler. Fakat arkadaşlarının, yaşadığı tensel maceraları ima etmeleri üzerine hangi mesleği seçerse seçsin mutlaka yazacağını söyler.

“Bir macerası olduğundan beri sadece okumanın verdiği zevkle yetinemeyeceğini anlamıştı. İki gündür anlatmak ihtiyacını duyuyordu. İçinde tahlil ifriti kımıldamış, bütün hayatı ona çözmesi icap eden bir muamma gibi uzatıyordu. Şüphesiz şimdi, derhal değil, Bir yığın eksiği vardı. Hiçbir hazırlığı yoktu. O kadar cahil, tecrübesiz, bütün hayatın yabancısıydı ki... Hafızasında daha şimdiden okumasını istediği bir yığın kitap ve muharririn adı sıralanmıştı. Bunlar yalnız adlarının cazibesiyle uzak adalar, tanımadığı kumsallar, haritada görünen o uçsuz bucaksız iklimler gibi kendisini çekiyordu. Ve şüphesiz bu muharrirlerin iklimine girince onun için bir yığın şey değişecek, başka türlü bir insan olacaktı" (s. 70-71).

Selim'i yazmaya iten bir kadınla yaşadığı ilk tensel hazzın günahı ve bundan duyduğu pişmanlıktır (Özcan, 2010/20, s.226-247). Bütün bunların ötesinde Çağın'ın da tespitiyle söyleyecek olursak, Tanpınar'ın hikâye ve romanlarında kadın başkarakter olarak seçilmemekle birlikte erkek kahramanların dünyasında vazgeçilmez bir yere sahiptirler (Çağın, 2010, s.261).

Yakup Kadri'nin sanatında bir dönüm noktası teşkil eden "Rahmet" (Karaosmanoğlu, 2017, s.167-190) hikâyesi sonuna eklenen Zeyil ve Hisse" kısmında kendi eserinin okur üzerinde hangi tepkileri uyandıracağına dair iddialarını ve bunların değerlendirmesini içermesi itibarıyla konumuz açısından ilgi çekici bir eserdir. Bu kısmı bir ilave olarak değil de esere dahil olarak düşünmemiz gerekir. Bu bağlamda bir yazma eyleminin, bir yaratma hadisesinin nasıl gerçekleştiğini göstermesi bakımından "Rahmet" $i$ de kanaatimizce değerlendirmek gerekir. Bunlardan daha da önemlisi Emin'in kadından vazgeçerek toplumun dertlerine yönelmesi Yakup Kadri'nin kendi sanat anlayışında bir evrilme süreci yaşamasıyla paralellik arz etmektedir (Durgun, 2012, s.173-186). Tabi onun toplumu anlatırken bile ferdin cephesinden hareket ettiğini hiç göz ardı etmemeliyiz.

Hikâyenin baş kişisi Emin, aslında bir sanatçı olmamakla birlikte çok okuyan, sanatkâr ruhlu bir karakterdir. Eser, Emin'in sevgilisine, aslında bir "kadın" cinsine, onun yaratılış gayesini ve erkeğin hayatındaki işlevlerini bir erkeğin gözünden sunan ve kutsal kitaplardaki hitabet tonu edasındaki tiradla başlar. Emin'in ruh azabı, aslında her zaman vardır, ancak asıl Balkan bozgunundan sonra İstanbul'a gelen Rumeli göçmenlerinin felaketli hayatlarına bizzat şahit olduktan sonra başlar. Kadının onu sarıp sarmalayarak birakmak istememesine mukabil Emin ondan kurtulmak, memleket insanının dertlerine ortak olmak ister. Yazar-anlatıcı Zeyil" ve 
Hisse" kısmında Emin'in “deniz"in ve "kadın”a nasıl tutkuyla bağlı olduğunu ve "kadın"la "deniz" in nasıl birleştiğini şöyle anlatır:

“..Sevdanın yegâne munsabı kadın değil mi? Arzın bütün suları, bütün nehirleri bin yerden, bin yoldan dönerek, dolaşarak nasıl denize doğru akıyorsa, bizim heyecanlarımız da bin yerden, bin yoldan dönerek, dolaşarak kadına ulaşıyor, hakiki munsabı, âkıbet, onda buluyor. Zaten, kadın da bir nevi deniz mi?" (s.171)

"Emin, bütün gençliğinde kendine denizden başka yoldaş bulmadı; çünkü o, kendini deniz kadar büyük ve kudretli sanıyordu. Ömrünün en güzel yılları bu sanış yüzünden gamlı ve kısır bir yalnızlık içinde geçti. Vakta ki, günün birinde, sevda çırçıplak geldi, kapısına vurdu, sandık ki ilaheler yatağına davet edildi ve gurur, şeytanî bir nefes gibi benliğini şişirdi. Çok sevdim sandiğ zamanlar hiç sevmediği zamanlardı. O, kadının sevgisinde kendini seyrederek sarhoş oldu." (s.189).

Burada yazarın Emin'i kurgularken “deniz"i ve "kadın"1 nasıl bir vasıtaya dönüştürdüğünü görüyoruz. Son derece "narsist" Emin, "deniz"i ve "kadın"1 kendi ruh halinin bir aynası gibi görür. Onlarda kendini yaşamak ister. Bu yüzden, kadının bir adı, ferdî bir tarafı bile yoktur. Asıl bunların darlığından kurtulduğunda kendini "engin denizlere benzeyen hür bir zerre gibi dolaşıyor hisseder ve ebedî ve hudutsuz bir şeye karışmış olmanın sarhoşluğunu yaşar (s.190). ${ }^{+}$

Tıpkı Raif Efendi'nin kendisinden iki yaş büyük Maria Puder'i zaman zaman annesinin yerine koyması gibi Kiralık Konak'ın (Karaosmanoğlu, 2008) Hakkı Celis'inin de Seniha'ya abla diye hitap etmesinde âdeta ona bir "anne" gibi sı̆̆ınma, onda kendini bulma emeli vardır. Hakkı Celis ilk başlarda Fecr-i Âticilerin tarzında şiirler yazar. Necibe Hanımefendi'nin Büyükada'ki köşkündeki partilerden birinde romantik şiirler okuması ve Seniha'ya aşkını ilan etmesi, alayla karşılanır. O gün sadece Seniha'dan değil Nuriye, Belkıs, Neyyire gibi diğer kadınlardan da nefret eder. Zamanla "şiirdeki aşk"la "hayattaki aşk"1n farklı olduğunu görmeye başlar (s.87). Ancak ara ara Seniha'nın kendisiyle “bir kedinin fareyle oynar gibi oynadığ zamanlarda" geceleri odasına kapanıp yeniden Seniha'nın gözleri, dudakları ve saçları için şiirler yazmaya başlar (s.95). Hele Seniha'nın hastalığı sırasında hem ferdî hayatında hem de edebî zevklerinde bir olgunlaşma yaşar (s.115). Ancak Seniha'nın Paris'e kaçması Hakkı Celis'i tekrar kendi yalnızlığına iter. Onun üzerinde asıl değiştirici darbeyi yapan, tıpkı Emin Bey'de olduğu gibi Balkan Harbi sonrası İstanbul sokaklarında karşılaştığı hazin manzaralar olur. Zaman zaman tereddütler yaşamakla birlikte Naim Efendi, Faik Bey ve Seniha gibilerin kanserli uzuvlar gibi

\footnotetext{
† Bu ifadeler, Yahya Kemal'in “Deniz” şiirindeki şu mısraları bize hatırlatır:
}

Mâdem ki deniz ruhuna sir verdi sesinden,

Gel kurtul o dar varlığının hendesesinden!

Son zevkin eğer aşk ise ummâna karış, tat! Boynundan o cânan dediğin lâşeyi silk, at! Kirpikleri süzgün o ihanet dolu gözler, Rikkatle bakarken bile bir firsatı özler.

Aldanma ki sen bir susamış rûh, o bir aç

Sen bir susamış ruh, o bütün ten ve biraz saç

Ummana çıkar burda bugün beklediğin yol,

At kalbini girdaba, açıl engine, ruh ol!” (Kendi Gök Kubbemiz, İstanbul Fetih Cemiyeti, 2008, s.80.) 
milletten koparılıp atılması gerektiğine karar verir ve Çanakkale'de milleti için vuruşmayı seçer (s.174-175). Edebiyat-1 Cedide ve Fecr-i Âticileri "zampara edebiyatı" yapmakla itham eder ve asıl edebiyatın milleti anlatan edebiyat olduğunu iddia eder (s.179-180). Onun böyle bir dönüşüm geçirmesinde, milletin içinde bulunduğu durumun trajikliğiyle birlikte asıl Seniha'yla arzuladığı gibi bir sevgiyi yaşayamaması sebeptir. Romanda onun millî edebiyat tarzında şiirler yazıp yazmadığından bahsedilmez, ancak Çanakkale'de şehit olduğu haberinin verildiği toplantıda Seniha sadece süsü ve güzelliği ile dikkat çeker (s.217).

Bir yazarın yaratma sürecini ve bu süreçte "kadın"ın işlevini konu alan en dikkate değer eserlerden biri, Peyami Safa'nın Bir Tereddüdün Romanı'dır (Safa, ?). Peyami Safa'nın diğer romanlarında olduğu gibi içerdiği birtakım teknik yenilikleriyle de kendinden söz ettiren bu eserde, özellikleri Peyami Safa'yla örtüşen bir yazar yer almaktadır. Onun yazarlık serüvenini iki kadın, Mualla (s.39, s.50-51) ve Vildan yönlendirir (s.108, s.130, s.165-166). Dolayısıyla Peyami Safa'nın romancillğının en karakteristik hususiyetlerinden biri olan Doğu-Batı çatışması, bu sefer iki kadın, iki kadın okur karakterinin etrafında şekil bulur. Fazıl Gökçek'in de belirtiği gibi,(Gökçek, 2015, s.213-229)

“... bu iki okur tipi, Mualla ve Vildan, birbirinden çok farklıdır. Mualla tereddüt yaşasa da mazbut, sınırları belli, tepkileri öngörülebilir, kısaca karmaşık olmayan bir okurdur. Ancak Vildan'ın temsil ettği ikinci okur tipi karmaşıktır; tepkileri öngörülemez ve ne zaman ne yapacağı belli olmaz. Bu yüzden yazar ondan uzak durmaya, aklını ve mantığını kullanarak Mualla'ya yaklaşmaya çalışır. Fakat Mualla'nın temsil ettiği okurun, yazarın yaratıcılığını kamçılamayacağı da açıktır. Bu durumda yazarın bir karar vermesi, “tereddüt”ünü aşması gerekecektir. Ya Mualla'ya sı̆̆ınarak rahat edecek, düz ve sade bir hayat yaşayacak, kısaca dünya mutluluğunu tercih edecek ya da Vildan'1 tercih ederek sürekli huzursuzluk yaşayacak, ancak sanatın ve yaratmanın dünyasında kalacaktır."

Buraya kadar üzerinde durduğumuz eserlerde yazar bir "erkek", "kadın" da onun sanatının "malzeme"si, bir "ilham kaynağı", "haz nesnesi" olarak kurgulanmaktadır. Böyle bir kabul, Batı tesirinde gelişen modern edebiyatımızda da devam ettirilmiştir. Ancak yeni eserlerde Tevrat ve İncil'den gelen, kadının Hz. Âdem'in kaburgasından yaratıldığını kabul eden inanç sisteminin belirleyici rolünün varlı̆̆ını da unutmamak gerekir. Kadının bir "haz" ve "ilham" kaynağı olarak görülmesi, geleneğin "erkek egemen edebiyat anlayışı" $n ı$ devam ettiren kadın yazarlarımızın eserlerinde de tekrarlanmıştır. Ancak kadın yazarlar, bir kadın sanatçı tasvir etmek istediklerinde, onu sanattan haz alan bir şair/yazar olarak kurgulamakla birlikte yaşadıkları ferdî ve toplumsal zorluklara direnen, ayakta kalma mücadelesi veren kadın karakterler olarak görmeyi tercih etmişlerdir. Romanlarda erkeği "rasyonellik"in; tabiatla birlikte kadını "duygu"nun temsilcisi olarak gören zihniyete aykırı tipler yaratmışlardır (Günaydın, 2018, s.38). Bu bağlamda kadın yazarlarımız eserlerinde kadın karakterleri modern toplumun gerektirdiği "birey"ler olarak görmeyi vurgulamışlardır. Eserlerde sanatla uğraşmaları hem ferdî zevklerini tatmin etmenin hem de "erkek-egemen toplum"a direnmenin neticesidir.

İlk kadın yazarlarımızdan Fatma Aliye'nin 1889/90'da yazdığı Udî (2012) romanında, çocukluktan itibaren babası tarafından hem hanende hem de sazende sıfatlarıla bir musıkîşinas olarak yetiştirilen bir kadının mücadele dolu hayat hikâyesi 
anlatılmaktadır (Karaca, 2012, s.13-26) . Bir kadın yazar olarak kadınların ferdî ve toplumsal hayatlarındaki meselelerini eserleri vasıtasıyla dile getirmeyi gaye edinen Fatma Aliye'nin (Argunşah, 2018) bu romanındaki Bedia'nın yaşadığı zorluklar karşısında ayakta durmasını sağlayan sahip olduğu mûsıkî sanatı olur. Babası ona, bu sanatın ilmini öğretir ve biraz bencilce de hareket ederek mûsıkîden başka bir şeyle ilgilenmesini istemez (s.37-49; s.59). Bedia, kanun ve kemandan sonra ud çalmayı da öğrenir. Şam'da gerek İslam gerekse Musevi kadınlardan oluşmuş, düğünlerde ve ziyafetlerde çalan sazende takımları arasında udu tanıyan kadınlar yokken, Fatma Aliye Bedia'yı bir ud üstadı olarak karakterize eder (s.45-46). Mûsıkî, Bedia'nın hayatının her aşamasında büyük bir önem teşkil eder. Sadece evlenmeden önce çocukluğu ve genç kızlığında değil, eşi Mail'in ihanetine uğradığı ve onu tamamen kaybettiği zamanlarda hayatının tek sı̆̆ınağı mûsıkî ve udu olur (s.72-73, 89, s.136). İsminin Bedia olması da bu bağlamda önemlidir.

Udî'den sonra eserlerindeki kültürlü ve özbenleri gelişmiş kadın karakterlerle dikkat çeken Son Eseri(Adıvar, 2018) romanı konumuz açısından hayli ilgi çekicidir. Halide Edip'in, “İlk Müslüman kadın resim öğretmenimiz" olarak bilinen ve aynı zamanda beste yapacak kadar müzikle de ilgilenen ressam Müfide Kadri(1890-1912)'nin hayatından esinlenerek kaleme aldığı bu romanı, Feridun Hikmet adlı bir roman yazarının ressam Kamuran'la yaşadığı aşkı konu almaktadır. Eser, hem bir romancinın hem de bir ressamın yaratma sürecine odaklanması bakımından konumuz açısından en dikkate değer örneklerdendir. Halide Edip, eserin içinde yazarı bir erkek, kadını da o yazara ilham kaynağı olarak kurgulamakla yukarıda hayli örnekler verdiğimiz erkek yazarlarla aynı bakış açısını paylaşır. Ancak burada sanatçı olan sadece Feridun Hikmet değildir, Kamuran da hem Feridun Hikmet'in hem de "Saadet Köşkü" adını verdiği ve hayalini kurduğu mutlu hayatın tablosunu yapar. Yazar, konumuz açısından hayli önemli olan bu tabloyla ilgili kısımları, kitabının ikinci baskısına ilave etmiştir (Enginün, 1995, s.187-188). Böylece sanatçı ve sanata malzeme olma bakımından erkekle kadın, kısmen de olsa onun romanında yer değiştirir. Diğer taraftan, romanın günlük ve mektuplar şeklinde kurgulanmasıyla tek yazar-anlatıcının hakimiyeti de önlenmiş olur. Kamuran'1 sadece Feridun Hikmet'in günlüklerinden değil aynı zaman Kamuran'la mektuplaşmalarından da tanırız. Kamuran, kendisini mektupla ifade ederken sadece Feridun Hikmet'e değil, kardeşi Asım'a da yazar.

Feridun Hikmet'in hayatında etkili olan kadınlar Kamuran, karısı Mediha, kızları Nerime ve akrabalarından Münire'dir. Kadın-erkek ilişkileri bakımından entrika romanlarının olay örgüsünü aratmayan bir yapıya sahip eserde, Feridun Hikmet'le Kamuran'ın karşılaşmaları hayli ilgi çekicidir. Feridun Hikmet'in karısı Mediha, Kamuran'ın abisi Roma Sefareti Başkâtibi Asım'la ilk evliliğini yapmıştır. Âsım'dan ayrıldığı halde kardeşi Kamuran'la görüşmeye devam eder. Bu vesileyle Feridun Hikmet'le Kamuran birbirleriyle daha yakından tanışırlar ve aralarındaki ilişki bu vesileyle başlar. A Kamuran, Feridun Hikmet'i iflas, Layemut gibi romanlarından tanımaktadır (s.49). Akrabalarından "hayli mütecessis ve çok hayalî” Münire de, her 
yazdığını okumakta, onunla edebiyat üzerine hareketli tartışmalar yapmaktadırlar. Bu tartışmalar, Feridun Hikmet'in yazarlığını besler (s.34):

Âsım Bey'in kardeşi diye mi sinirine dokunuyor?

-Hayır.

-O halde hayır alameti değil.

-Bilakis... En hayırlı alamet.

Biraz sinirli:

-Bilmece gibi konuşacağına niçin sinirlendiğini anlatsana!

-Peki. Sırf eserlerimi sevdiği için.

-İnanayım mi?

-Nasıl istersen. Bende bu bir illet. Eserimi hırpalayan münekkide kızarım fakat fazla methedene de kin tutarım. Sebebini ben de pek iyi izah edemiyorum. Fakat eserlerini seven kadın olursa onlara daha çok kin tutuyorum.

-Anladım, seni erkek diye değil, sanatkâr diye sevdikleri için kadınlara kin tutuyorsun.

-Bilemedin. Evvelâ bazıların yazdığı mektupların mübalağası için, sonra da sanatkârı methederek o yoldan beni cezbetmek istedikleri için." (s.38.)

Feridun Hikmet' in romancılığını en çok etkileyenler kadınlardır. İtici fizikî özellikleri ve güçlü ilişki ağlarıyla sürekli varlığını görünür kılmak isteyen Mediha'ya karşılık Kamuran hem güzelliği, hem de hayatının her anına yansıyan estetik zevkleriyle Feridun Hikmet'i yokluğunda bile cezbeder. Diğer taraftan Mediha'nın ve Münire'nin aşırı alafrangalıklarına rağmen Kamuran, dıştan Frenkleşmiş gözükmekle birlikte iç âlemi yerli ve millidir. Aslında Mediha da, Feridun Hikmet'in Kamuran'ın okuduğunu söylediği iflas romanına konu olmuştur. Kamuran, romandaki karikatürleşmiş Mediha'yı, abisinin hayli mübalağalı çizdiği portresine göre daha gerçekçi bulur. Feridun Hikmet'i ise hem şahsî hem de sanat hayatında en çok etkileyen Kamuran olur:

Merdivenleri basamak basamak çıkarken durup birbirimize bakıyoruz; ben, her duruşta onun yeni bir güzelliğini seziyorum. Birbirimize çok yakınız. Yürürken en çok endamının inceliği, zarafetiyle gözüm meşgul oluyor. Kendi kendime, "Neden şimdiye kadar böyle bir örnek bulup romanlarıma koymadım?" diyorum. Çünkü bu güzelliğin bana insan olarak verdiği zevk yanında romancının serin kafalı tetkiki hiç zail olmadı. (s.41).

$\mathrm{Bu}$ kadar güzel bir kadının ancak resimle ifade edilebileceğine inanır. Münire'nin onu, “Bir romana koyamaz misın? sorusuna hayır cevabını verir:

-Çünkü romancı bir insanın yüzünden ziyade içiyle meşgul olur. Ne bileyim belki onun içini tarif etmek için üç-dört sayfa yeter, herhalde kuru hisli olacak, bu yaşa kadar evlenmemiş.. Ama güzel... Çok güzel. (s.43).

Feridun Hikmet, zamanla onu daha yakından tanıyacak ve tanıdıkça ona tutkuyla bağlanacaktır. Ve aslında yazmadığına hayıflandığı ve yazılmayacağını düşündüğü halde bu kadının romanını yazmaktadır. Eserde Feridun Hikmet'in İttihat ve Terakki sempatizanı kardeşi İbrahim'in hayatından esinlenerek Maksat Adam başlıklı bir roman yazdığına da değinilir. Halide Edip'in Jön Türklerle ilgili eleştirilerini de ihtiva eden bu kısımda bizim için önemli olan, Feridun Hikmet'i bu konunun, yani yakından tanıdığ 1 bir insanın romanını, "realist" bir tarzda yazmanın pek cezbetmediğidir. O tekrar Kamuran'ın gizemli dünyasını keşfetmeye yönelecektir.

Hayatta Kamuran'dan sonra kendisini en çok etkileyen ikinci insan kızı Nerime'nin vefat haberi alır almaz yola çıkan Feridun Hikmet, Kamuran'a bıraktığı mektupta, 
kendisini hem Feridun Hikmet hem de yazar olarak çok sevdiği için adına layık, zamanla unutulmayacak "muhalled" bir eser yazmak istediği halde muvaffak olamadığını, bunun yerine ömrünü ona ithaf ettiğini, bu "son eseri"nin herhangi bir şaheserden çok daha Kamuran'a layık olduğunu ifade eder (s.165-166). Böylece Halide Edip'in Son Eseri, yazılmadığına hayıflanılan bir romanın yazılış öyküsü olur. Bunun yanı sıra Halide Edip, diğer yazarlardan farklı olarak "kadın"ı sadece sanatın nesnesi olarak kurgulamaz, Kamuran Feridun Hikmet'in tablosunu yaparken kendi sanatını icra eder. Feridun Hikmet, ona "roman" yerine ömrünü ithaf ederken, o aşklarını tabloyla ölümsüzleştirir. Enginün, Halide Edip'in, 1912'de Tanin'deki ilk tefrikası ve 1919'daki ilk baskısından sonra romanın 1939'daki ikinci baskısında Kamuran'ın ölümü ve sanatına dair yaptığı ilaveleri ve yenilikleri anlamlı ve önemli bulur (Enginün, 1995, s.194-195).

Safiye Erol'un Ciğerdelen (2001) ve Ülker Fırtınası (2001) romanlarında da sanatçı kimlikleri ön plana geçen kadın karakterlerden bahsedebiliriz. Eserlerinde hem modern hem de manevi ve millî değerleri sağlam kadınlara yer vermekle dikkat çeken Erol'un Ciğerdelen'indeki Cangüzel/Canzi kendi atalarının Rumeli'deki romantik ve hüzünlü aşk hikâyelerinin de eşlik ettiği tarihî serüvenlerini hamasî ve lirik bir üslupla kaleme alan hikâyeler yazar. Canzi, muharrir olmanın ötesinde kolejlerden birinde öğretmendir, "dansözdür, folklore ve köy enstitülerine merakı vardır" (s.21). Para ve hırs düşkünü ilk eşinden ayrılmak üzereyken tanıştığ Turhan'la yaşadığı aşkın şekillenmesinde bu hikâyeler önemlidir. Almanya'daki tahsilini başarıyla tamamladıktan sonra ülkesine dönen mimar Turhan'ın en büyük emellerinden biri doğup büyüdüğü Trakya coğrafyasının millî imarını görmektir. Dolayısıyla aynı coğrafya ve soydan gelen Turhan'la Canzi'nin aşkları, yaşadıkları hayli alafranga ortamlara ve ilişki ağlarına rağmen, ortak millî ve manevî bir atmosferde neşvünema bulur. Safiye Erol, bir kadın yazarı eserinin esas karakteri olarak kurgularken onu anlatmak için Turhan'ı, dolayısıyla bir erkeği yansıtıcı merkez olarak seçer. Canzi'nin yazdığı hikâyeler ise III. Şahıs ağzından anlatılır. Turhan, Canzi'nin "müşterek soylarının maceraları"nı anlattığı hikâyeleri "yavrumun, sevdiğimin eserleri" diye takdim eder(s.52, 118). Osmanlı'nın Rumeli'deki seferleri sırasında Estergon Kalesi karşısında stratejik nokta olan Ciğgerdelen'in II. Viyana Seferi sırasında kaybedilmesiyle Balkanlar'daki çekilme de başlamış olur. Canzi'nin bu 1stıraplı geri hadiseden hareketle yazdığı “Ciğerdelen Efsanesi", hem kendisini hem de Turhan'ı olgunlaştırır. Asıl önemlisi Rumeli'den ve atalarından gelen milliyetçi ruh, Canzi'nin hamile kalması; Turhan'ın da mimarî projelerini gerçekleştirmesiyle yeniden canlanır (Dumantepe, 2004, s.71). Safiye Erol'un kendi fikrî dünyasına uygun olarak burada, yazdıklarıyla "yeniden doğuş miti"ni, idealize ettiği bir kadının şahsında işlediğini söyleyebiliriz.

Safiye Erol'un Ülker Fırtınası'nda da çileli bir aşk hayatının içindeki bir kadının sanatıyla birlikte kendi dünyasına sığınmasının hikâyesini okuruz. Viyana'da 7 yıl müzik tahsili gördükten sonra ülkesine dönen Nuran Yerli'nin amacı Türk mûsıkîsine yeni bir ruh vermektir (s.16). Bunun için katıldığı fasıllarında sürekli Batı mûsıkîsiyle kendi mûsıkîmizi mukayese eder ve buradan yola çıkarak kendi 
kimliğini tanıma ve tanımlama endişesine düşer (s.18-24). Aile dostları Mehpare hanımın yalısındaki mûsıkî ziyafetinde tanıştığı udî Sermet'le yaşadıkları aşktaki iniş-çıkışlar, Nuran'a sanatının önemini daha çok hissettirir (s.157). Kendisini sevdiğini söylediği halde evliliğini yürütmeye çalışan Sermet'in ihaneti üzerine yaptığ1 "Yehuda Senfonisi" isimli bestesi, bu çileli yolculuğun ürünüdür (s.210). Ancak onu kendi beninden geçirerek mutlak huzurun kaynağı Allah'1 bulmaya sevkeden Bektaşi şeyhi babası Ali Fethi Bey olur (s.130-132). Nuran'ın hayatında esas olan Sermet'tir ancak mûsıkîyle ilgili planlarını da ihmal etmez (s.152, 176-177). Sermet'e hem Müzeyyen'den ayrılmayı hem de alaturka mûsıkîyi bırakıp Garp mûsıkîsine geçmeyi teklif eder (s.180). Nuran, alaturka mûsıkinin yasaklandığı dönemde Türk operasının tesisinde görevlendirilir. Kendini tamamen sanatına verir. Ruhen de babasının izinden giderek olgunlaşmayı tercih etmiştir. Ülker Fırtınası, aşkta ve sanatta olgunlaşma mücadelesi veren bir kadının romanı olarak karşımıza çıar.

Günümüz Türk edebiyatının üretken kadın yazarlarından Sevinç Çokum, Kırmalı Etekler'de (2014) Çise isimli bir kadının yazarlık serüvenini, ferdî ve toplumsal hayattaki çok çeşitli ve farklı hadiselerle birlikte işler. Eserde bir taraftan Çise'nin Nuh tufanından hareketle bir romanı oluşturma sürecine yer verilirken bir taraftan da bir kadın ve yazar olarak değişen hayat şartları ve anlayışları karşısında ayakta kalabilme mücadelesi üzerinde durulur. Çokum, diğer romanlarında olduğu gibi bu romanında da esas mevzunun yanı sıra, çağrışımlar, hatıralar, anekdotlar vasıtasıyla birçok meseleyi ana mevzuyla birlikte işleme peşindedir. Çise'nin ilk evliliğinin mutsuzlukla bitmesinin sebebi başta kocası olmak üzere etrafındaki herkes tarafından yazarlığının küçümsenmesidir. İkinci evliliğini kendisini anlayan gazete ve şehir yazıları yazan biriyle yapar. Ancak bu sefer de karşısına hayatın hızla değişen temposuna ayak uyduramayışı, bir "piyasa ve moda yazarı" olamayışı, "tutunamayışı" çıkar. Romanda genç bir kadının söyleşisine verdiği cevaplarda,(s.269-273) Çokum'un kendi yazarlık hayatındaki endişeleri görebilmek mümkündür. Bir röportajda her ne kadar kişilerinin erkek veya kadın olmasının kendisi için bir önem taşımadığını belirtse de kadın yazarların kadın kahramanları daha çok öne çıkardığını, daha samimi ve daha canlı yarattıklarını da vurgulamayı ihmal etmez. Ona göre kadın kahramanlar, 70'li yıllardan itibaren daha çok kendileri olmaya başlamışlardır (Kaftar, 2018, s.71).

Edebiyat tarihimizde kadın yazarların kaleme aldıkları eserlerde kadın karakterlerin bir yazar olarak kurgulandığı eserlerin sayısı elbette fazladır. Bu bağlamda bir kadının günlüğü, hatıra defteri şeklinde kurgulanmış eserler aklımıza gelebilir. Söz gelimi Tezer Özlü'nün tam da roman türüne dahil edilemediği için anlatı olarak nitelendirilen, gezi yazılarının imkanlarında da faydalanan Yaşamın Kıyısına Yolculuk (Özlü, 2015) adlı eserinde bir kadın yazarın yalnız, hüzünlü ve karamsar izlenimlerine tanık oluruz. Otobiyografik özellikler taşıyan bu anlatıda bir kadın yazarın bir kadını kurgularken onu "aşk" ilişkileri çerçevesinden ziyade bir kadın ve bir birey olarak canlandırma endişelerini görmek mümkündür. Öykündüğü Pavase, 
Kafka gibi yazarlardan alıntılar yaptığı metninde şu epigraf, bahsettiğimiz hususa bir örnek teşkil etmektedir:

"Öykü ve şiir yaratmak için doğmuş olanlar, âş̧k olmakla yetinemezler, çünkü aşkın sanatsal bir yapıtı oluşturacak entelektüel örgüsü yoktur." (s.20)

\section{Sonuç}

"Kadın", daha çok "erkek"lerin temsil ettiği edebiyat dünyasının en temel mevzularından ve kişilerinden biridir. Bu çizgideki eserlerde kadınlar, ya "hayal edilen sevgili, tanrıça (anima arşetipi) ve afet kadın (meş'um kadın) olarak karşımıza çıkarlar. İncelediğimiz sanatçı romanları içerisinde yazarın erkek ve kadın olması önemli bir meseledir. Erkek yazarlar içerisinde sanat endişesiyle kadına bakışı en estetik şekilde işleyen yazarlar Halit Ziya, Sabahattin Ali, Yakup Kadri ve Tanpınar'dır. Halit Ziya'nın ve Tanpınar'ın naif karakterlerinin sanat hayatları, hatta ferdî hayatları "kadın"la var olur, "kadın"la yok olur. Ancak eserlerinin esas karakterleri kadın değil, erkektir. Bu tespit, Sabahattin Ali'nin naif Raif Beyi için de geçerlidir. Ancak onun "Kurtarılamayan Şaheser"inde ve Yakup Kadri'de kadın "meşum"laşır ve sanatkârane yaratıcılık için ondan vazgeçilmesi gerekir ve fakat ideallere ulaşmak için "kadın"ın varlığı şarttır.

Kadın yazarlar sanatçı romanlarında hemcinslerini çizerken onların en çok her türlü zorluk karşısında ayakta kalmalarına vurgu yaparlar ve kadınların hem ferdî hem de toplumsal hayatlarındaki var oluş çabalarına önem verirler. "Kadın" bir erkek yazarın eserindeki "ilham perisi" ve "haz kaynağı" olma vasfını kısmen de olsa yitirir. "Kadın"ın var olma mücadelesi içerisinde "sanat"la uğraşmaları bu bağlamda çok önemlidir. Ancak erkek yazarlardan farklı olarak sanat sadece bir araç değil, bir amaçtır da. Bu yüzden kadın sanatçı romanlarındaki kadınlar, bilhassa Fatma Aliye ve Halide Edip'in eserlerinde örneklerini gördüğümüz gibi, edilgen, naif değil, güçlü ve iradeli tiplerdir. Bu iki ismin Türk edebiyatındaki feminist eğilimlerin önde gelen isimleri arasında anılması boşuna değildir. Tezer Özlü, sanatçı bir kadının hüzünlü yalnızlığını işlerken özgürlük arzularını asla ihmal etmez.

Sanat ve kadının niçin hep birlikte düşünüldüğünü kanaatimce Tanpınar'ın şu misraları izah eder:

Niçin sen yaratmadın bu dünyayı?

Ellerinin mesut işaretlerinden

Daha güzel doğardı eşya!

Daha zengin olurdu aydınlık

Kendi karanlığından çağırsaydı sesin,

Sular başka türlü akardı

Sert kayalardan göklere doğru

Büyük, mavi, aydınlık sular! (1989, s.74-75). 


\section{Kaynakça}

Adıvar, H.E. (2018). Son Eseri, Can Yayınları, İstanbul.

Argunşah, H. (11.11.2018). "Fatma Aliye", TEIS.

Beyatlı, Y.K. (2008). Kendi Gök Kubbemiz, İstanbul Fetih Cemiyeti.

Çağın, Ş. (2010). "Ahmet Hamdi Tanpınar'ın Roman ve Hikâyelerinde Kadın İmajı”, Ömer Faruk Huyugüzel'e Armağan, Ege Üniversitesi Yayınları, s. 261-275.

Çokum, S. (2014), Kırmalı Etekler, Kapı Yayınları.

Dumantepe, S. (2004). Safiye Erol'un Eserlerinde Zaman, Mekân ve İnsan, Manisa Celal Bayar Üniversitesi Sosyal Bilimler Enstitüsü, YYL, Manisa.

Durgun, H. (Eylül 2012). "Ferdiyetçilik"ten “Toplumsalcıllk"a Geçişte Yakup Kadri'nin

"Rahmet" Hikâyesi", TYB Dil, Edebiyat ve Sosyal Bilimler Dergisi, Y.2, S.6, s.173-186.

Enginün, İ. (1995). Halide Edip Adıvar'ın Eserlerinde Doğu ve Batı Meselesi, MEB Yayınları.

Erol, S. (2001). Ciğerdelen, Kubbealtı Neşriyatı, İstanbul.

Erol, S. (2001). Ülker Fırtınası, Kubbealtı Neşriyat, İstanbul.

Gökçek, F. (2015). “Peyami Safa'nın Anlatım Teknikleri Bakımından Türk Romanına Katkısı

Üzerine Bazı Dikkatler", Peyami Safa, Kültür Bakanlığı Yayınları, Ankara, s.213-229.

Günaydın, A.U. (2018). Kadınlık Daima Bir Muamma, Osmanlı Kadın Yazarların Romanlarında Modernleşme, Metis Yayınları, İstanbul.

Fatma Aliye, (2012). Udî, Hazl: Şahika Karaca, Kesit Yayınları, İstanbul.

Huyugüzel, Ö.F. (2018). "Bildungsroman", Eleştiri Terimleri Sözlüğü, Dergâh Yayınları, İstanbul, s.86-88.

Kaftar, D. O. (2018). "Sevinç Çokum Söyleşisi”, Bizim Külliye, S.75, Yı1:19, s. 68-76.

Kaplan, M. (1987). "Bir Şairin Romanı: Huzur", Türk Edebiyatı Üzerinde Araştırmalar 2, Dergâh Yayınları, İstanbul, s.361-425.

Kaplan, M. (1987). Tevfik Fikret, Devir-Şahsiyet-Eser, Dergâh Yayınları, İstanbul.

Karaca, Ş. (2012). "Fatma Aliye ve Udî Üzerine”, Udî, s.13-26.

Karaosmanoğlu, Y.K. (2008). Kiralık Konak, İletişim Yayınları, İstanbul.

Karaosmanoğlu, Y.K. (2017). "Rahmet”, Bir Serencam, İletişim Yayınları, İstanbul, s.167-190.

Özcan, N. (2010/20). “Tanpınar’ın Günlüklerinden Bakıldığında Aydaki Kadın”, Türkbilig, s. 226- 247.

Özlü, T. (2015). Yaşamın Kıyısına Yolculuk, YKY, İstanbul.

Sabahattin Ali (2015). "Kurtarılamayan Şaheser", Değirmen, YKY, İstanbul, s.24-37.

Sabahattin Ali (2015). “Viyolensel”, Değirmen, YKY, İstanbul, 2015, s.42-50.

Sabahattin Ali (2004). Kürk Mantolu Madonna, YKY, İstanbul.

Safa, Peyami (Tarihsiz), Bir Tereddüdün Romanı, Ötüken Yayınları, İstanbul.

Şahin, İ. (2012). Haz ve Günah, Kapı Yayınları, İstanbul.

Tanpınar, A.H. (1989). Bütün Şiirleri, Dergâh Yayınları, İstanbul.

Tanpınar, A.H. (1987). Aydaki Kadın, Adam Yayınları, İstanbul.

Tarhan, A.H. (2000). Tiyatroları 4, Eşber/Sardanapal, Hazl.: İnci Enginün, Dergâh Yayınları, İstanbul.

Tevfik Fikret. (2017). Rübab-ı Şikeste, Hazl.: Sabahattin Çağın, Dergâh Yayınları, İstanbul. İstanbul.

Uşaklıgil, H.Z. (2017). Bir Ölünün Defteri, Hazl.: Pürlen Bağdatoğlu, Dergâh Yayınları,

Uşaklıgil, H.Z. (2016). Mai ve Siyah, Hazl.: Ece Serrican, Dergâh Yayınları, İstanbul. 